DOI: $10.1590 / 1089-6891 v 16 i 327069$

MEDICINA VETERINÁRIA

\title{
GESTATIONAL ECHO BIOMETRY IN BRACHYCEPHALIC PREGNANT BITCHES
}

\section{ECOBIOMETRIA GESTACIONAL EM CADELAS GESTANTES BRAQUICEFÁLICAS}

\author{
Marcus Antônio Rossi Feliciano ${ }^{1^{*}}$ \\ Giovanna Serpa Maciel ${ }^{1}$ \\ Leandro Nassar Coutinho² \\ Vívian Tavares Almeida ${ }^{1}$ \\ Ricardo Ramirez Uscategui ${ }^{1}$ \\ Wilter Ricardo Russiano Vicente ${ }^{1}$
}

1Universidade Estadual Paulista, Faculdade de Ciências Agrárias e Veterinárias, Jaboticabal, SP. Brasil.
2Universidade Federal Rural da Amazonia, Belém, PA, Brasil.
${ }^{*}$ Autor para correspondência - marcusfeliciano@yahoo.com.br

\begin{abstract}
Ultrasonography is an accurate pregnancy diagnostic method, besides being completely innocuous for female and fetuses evaluation. The objective of this paper was to determine the reference values for gestational echo biometry of different breeds of bitches. A total of 25 multiparous females were included in the experiment, five English Bulldog bitches, five Pugs and 15 Shih Tzu, weighing 4-25 $\mathrm{kg}$ and aged 4-6 years. The echo biometric assessments were performed during the 2nd, 5th, 6th, 7th and 8th weeks of pregnancy, including gestational vesicle diameter, femur length, placenta thickness, parietal diameter, liver, heart and abdominal diameter and area. Early echo biometric study started at the second week of gestation. Measurements like fetal heart and liver diameter and area are still poorly studied, but can provide useful information for early detection of congenital anomalies that may reduce the viability of pregnancy. The significant results $(\mathrm{P}<0.001)$ obtained for biometrics $(\mathrm{P}<0.001)$ of the parietal $\left(\mathrm{r}^{2}=81 \%\right)$ and abdominal diameter $\left(\mathrm{r}^{2}=86 \%\right)$, abdominal area $\left(r^{2}=80 \%\right)$, femur length $\left(r^{2}=84 \%\right)$, cardiac length $\left(r^{2}=79 \%\right)$, width $\left(r^{2}=79 \%\right)$, area $\left(r^{2}=\right.$ $82 \%)$ and volume $\left(r^{2}=72 \%\right)$ and liver area $\left(r^{2}=71 \%\right)$ in brachycephalic conceptus may help to assess the development of fetuses, complementing the conventional gestational ultrasound of bitches and become a model for the study in other breeds of dogs and alternative animal species.
\end{abstract}

Keywords: canines; gestational diagnosis; ultrasonography.

\section{Resumo}

O exame ultrassonográfico é um meio de diagnóstico preciso para avaliação da gestação, além de ser totalmente inócuo para fêmea e fetos. Objetivou-se com este estudo determinar os valores de referência para a ecobiometria gestacional em cadelas de diferentes raças. Foram utilizadas 25 fêmeas multíparas, sendo cinco cadelas Bulldog inglês, cinco Pugs e 15 Shih Tzu, pesando de 4 a 
$25 \mathrm{~kg}$ e com idade entre 4 a 6 anos. As avaliações ecobiométricas como diâmetro da vesícula gestacional, comprimento femoral, espessura da placenta, diâmetro parietal, diâmetro e área abdominal, hepática e cardíaca foram realizadas durante as $2^{\mathrm{a}}, 5^{\mathrm{a}}, 6^{\mathrm{a}}, 7^{\mathrm{a}}$ e $8^{\mathrm{a}}$ semanas gestacionais das cadelas. $\mathrm{O}$ estudo ecobiométrico em cadelas gestantes foi precocemente iniciado a partir da segunda semana gestacional. Mensurações pouco estudadas como o diâmetro e área hepática e valores ecobiométricos do coração fetal, podem fornecer informações úteis para a detecção precoce de anomalias congênitas que podem comprometer a viabilidade gestacional. Os resultados significativos $(\mathrm{P}<0.001)$, obtidos para a biometria do diâmetro parietal $\left(\mathrm{r}^{2}=81 \%\right)$ e abdominal $\left(\mathrm{r}^{2}\right.$ $=86 \%)$, área abdominal $\left(r^{2}=80 \%\right)$, comprimento do fêmur $\left(r^{2}=84 \%\right)$, comprimento $\left(r^{2}=79 \%\right)$, largura $\left(\mathrm{r}^{2}=79 \%\right)$, área $\left(\mathrm{r}^{2}=82 \%\right)$ e volume $\left(\mathrm{r}^{2}=72 \%\right)$ cardíaco e área hepática $\left(\mathrm{r}^{2}=71 \%\right) \mathrm{em}$ conceptos braquiocefálicos, podem ajudar a avaliação do desenvolvimento dos fetos, complementando a ultrassonografia gestacional de cadelas e como modelo para o estudo em outras raças de cães e espécies animais.

Palavras-chave: caninos; diagnóstico gestacional; ultrassonografia.

Recebido em: 29 out. 2013

Aceito em: 06 fev. 2015

\section{Introduction}

Ultrasonography is an accurate pregnancy diagnostic method, being innocuous for females and fetuses. It can be used to confirm pregnancy, estimate gestational age, assess the condition of the ovaries and uterus, check for signs of fetal viability, diagnose abnormal conditions related to pregnancy, such as less developed fetuses in relation to gestational age, fetal reabsorption and abortion $^{(1)}$.

According to Miranda and Domingues ${ }^{(2)}$, the echo biometry is an important technique to study gestational structures and anatomical assessment of the fetuses throughout development and not just for predicting gestational age.

The biometric study of gestational vesicular and fetal structures in pregnant bitches of English Bulldog, Pug and Shih Tzu breeds provides relevant information on the development of canine fetuses, complementing the conventional gestational ultrasonography ${ }^{(3)}$. In order to achieve early diagnosis of fetal development disorders, and considering the importance of ultrasonography as a diagnosis method for fetal viability in dogs, the aim of this study was to determine reference values for gestational echo biometry in English Bulldog, Pug and Shih Tzu bitches.

\section{Material and Methods}

The present study was conducted following the approval of the Animal Ethics and Welfare Committee of the School of Agrarian and Veterinary Sciences of Sao Paulo State University (protocol N. 017 314/10). Twenty-five healthy multiparous females, English Bulldog (n=5), Pugs $(n=5)$ and Shih tzu $(n=15)$, weighing 5-25 kg and aged 4-6 years of age were selected for the current study after physical and obstetric examinations. 
The kennel owner was trained to detect the first signs of pro-oestrus to determine the ideal time for mating. Confirmation was determined by observing the signs of oestrus (i.e., acceptance of copulation by the female) and by vaginal cytology. The female and male were mated for three days, or artificial insemination was performed. In the case of natural mating, the acceptance to the male was observed for confirmation ${ }^{(1)}$.

Pregnancy diagnosis was carried out according to methodology employed in other studies ${ }^{(1)}$ with 7.5 and $12.0 \mathrm{MHz}$ linear transducers and MyLab VET 30 ultrasound (US) equipment (ESAOTE, Italy). Weekly professional ultrasonographic examinations using B-mode were performed between the 2nd, 5th at 8th weeks of pregnancy.

During the 2nd week of pregnancy, the laterolateral external (ELL), internal (ILL), dorsoventral external (EDV) and internal (IDV) diameters of gestational vesicles were evaluated (Figure 1).

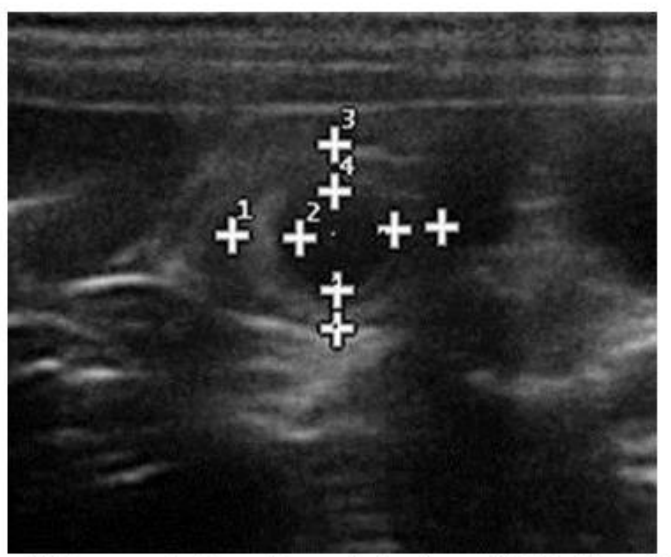

Figure 1: Ultrasound image of the gestational vesicle in a Shih Tzu bitch. Note the measurements of the diameters: external (1) and (2) internal laterolateral; and external (3) and internal (4) dorsoventral.
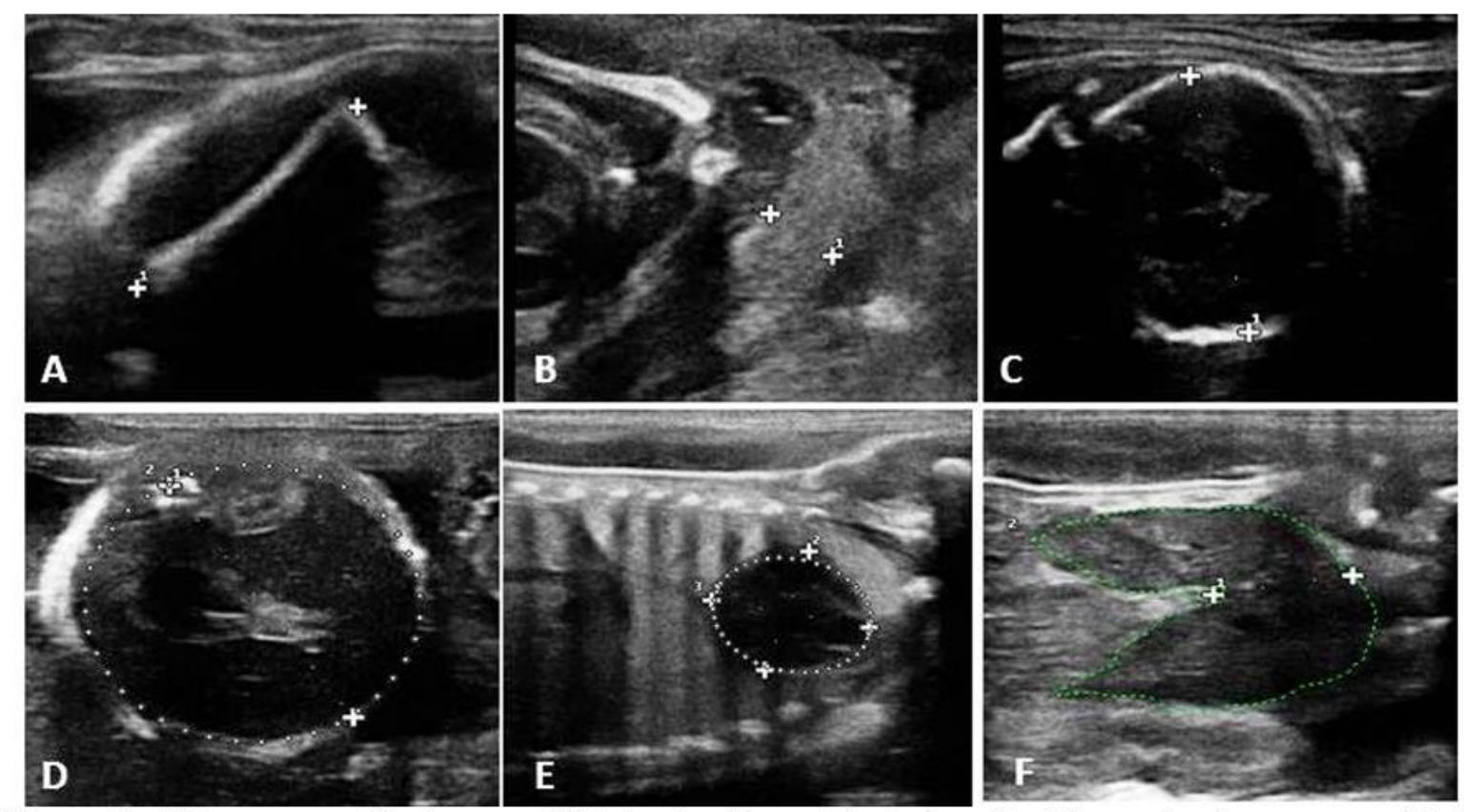

Figure 2: Ultrasonographic image of fetal echo biometric during the 8th week of pregnancy. Note the evaluation of fetal femur length (A), placenta thickness (B) parietal diameter (C), abdominal area and diameter (D), cardiac measurements (E), liver diameter and area (F).

For the 5th, 6th, 7th and 8th gestational weeks, we measured fetal femur length, placenta thickness, 
parietal and abdominal diameter, abdominal area, liver diameter, liver area, cardiac measurements (length, width, area and volume) (Figures 2A, B, C, D, E). Liver echo biometric values were measured in longitudinal view of the fetuses, using the major diameter as the area and the shortest distance between the abdominal liver contact surface to the fetal diaphragm as the liver diameter (Figure 2F).

The data were analysed for normality of residuals and homogeneity of variances ( $F$ test). The Minitab $14^{\mathrm{TM}}$ statistical software was used for analysis. The data were analysed for residual normality. Raw or transformed averages were evaluated using the linear regression analysis by minimum squares $(\mathrm{P}<0.05)$. Descriptive statistics were performed and the data were presented as mean \pm standard error.

\section{Results and Discussion}

The mean pregnancy period was 58 days post-ovulation. The mean number of puppies per pregnancy was four, all healthy. The pregnancy diagnosis was confirmed at $14.24 \pm 2.17$ days after mating or artificial insemination, after a single ultrasonographic exam. Echo biometric values of gestational vesicles and fetus are shown in Tables 1, 2, 3, 4 and 5.

Table 1: Mean values of diameters (external and internal laterolateral; and external and internal dorsoventral) of the gestational vesicles of English Bulldog, Pug, Shih Tzu bitches, during the 2nd week of pregnancy

\begin{tabular}{ccccc}
\hline & \multicolumn{4}{c}{ Mean values (cm) } \\
\cline { 2 - 5 } Breed & ELL & ILL & EDV & IDV \\
\hline English Bulldog & $0.94 \pm 0.18$ & $0.27 \pm 0.10$ & $0.82 \pm 0.17$ & $0.23 \pm 0.08$ \\
Pug & $0.89 \pm 0.38$ & $0.42 \pm 0.30$ & $0.90 \pm 0.38$ & $0.42 \pm 0.32$ \\
Shih Tzu & $0.81 \pm 0.23$ & $0.30 \pm 0.17$ & $0.72 \pm 0.18$ & $0.25 \pm 0.14$ \\
P-value & 0.59 & 0.43 & 0.32 & 0.20 \\
\hline
\end{tabular}

* Significant for P <0.05. ELL: external laterolateral; ILL: internal laterolateral; EDV: external dorsoventral; IDV: internal dorsoventral.

Table 2: Mean values of fetal biometry (cranium, abdominal, femoral, placentary, cardiac and hepatic) in English Bulldog during the 5th and 8th weeks of pregnancy

\begin{tabular}{cccccccc}
\hline Variables & 5th & 6th & 7th & 8th & Regression & P-value & R $^{\mathbf{2}}$ \\
\hline $\mathrm{PD}(\mathrm{cm})$ & $0.93 \pm 0.34$ & $1.45 \pm 0.33$ & $1.98 \pm 0.33$ & $2.24 \pm 0.49$ & $28.1+10.3^{*} \mathrm{PD}$ & $<0.001$ & $67 \%$ \\
$\mathrm{AD}(\mathrm{cm})$ & $1.29 \pm 0.22$ & $2.32 \pm 0.27$ & $3.18 \pm 0.30$ & $4.08 \pm 0.23$ & $25.8+7.2^{*} \mathrm{AD}$ & $<0.001$ & $95 \%$ \\
$\mathrm{AA}\left(\mathrm{cm}^{2}\right)$ & $1.49 \pm 0.50$ & $4.35 \pm 0.89$ & $8.02 \pm 1.26$ & $14.63 \pm 2.24$ & $35.0+1.5^{*} \mathrm{AA}$ & $<0.001$ & $90 \%$ \\
$\mathrm{FL}(\mathrm{cm})$ & $0.46 \pm 0.11$ & $0.82 \pm 0.12$ & $1.32 \pm 0.24$ & $1.69 \pm 0.14$ & $29.2+15.1^{*} \mathrm{FL}$ & $<0.001$ & $90 \%$ \\
$\mathrm{PT}(\mathrm{cm})$ & $0.41 \pm 0.06$ & $0.51 \pm 0.03$ & $0.60 \pm 0.07$ & $0.65 \pm 0.02$ & $7.88+68.8^{*} \mathrm{TP}$ & 0.12 & $\mathrm{NA}$ \\
$\mathrm{CL}(\mathrm{cm})$ & $0.63 \pm 0.08$ & $1.17 \pm 0.22$ & $1.65 \pm 0.10$ & $1.80 \pm 0.08$ & $25.1+15.5^{*} \mathrm{CL}$ & $<0.001$ & $89 \%$ \\
$\mathrm{CW}(\mathrm{cm})$ & $0.50 \pm 0.06$ & $0.87 \pm 0.18$ & $1.27 \pm 0.10$ & $1.43 \pm 0.15$ & $26.0+19.1 * \mathrm{CW}$ & $<0.001$ & $87 \%$ \\
$\mathrm{CA}\left(\mathrm{cm}^{2}\right)$ & $0.25 \pm 0.05$ & $0.79 \pm 0.28$ & $1.56 \pm 0.16$ & $1.78 \pm 0.26$ & $33.0+11.4^{*} \mathrm{CA}$ & $<0.001$ & $88 \%$ \\
$\mathrm{CV}\left(\mathrm{cm}^{3}\right)$ & $0.08 \pm 0.02$ & $0.48 \pm 0.24$ & $1.31 \pm 0.34$ & $1.50 \pm 0.43$ & $36.4+10.8^{*} \mathrm{CV}$ & $<0.001$ & $80 \%$ \\
$\mathrm{HD}\left(\mathrm{cm}^{2}\right.$ & $0.56 \pm 0.04$ & $0.78 \pm 0.50$ & $1.16 \pm 0.17$ & $1.39 \pm 0.23$ & $31.3+14.5^{*} \mathrm{HD}$ & $<0.001$ & $60 \%$ \\
$\mathrm{LA}\left(\mathrm{cm}^{2}\right)$ & $1.06 \pm 0.18$ & $2.24 \pm 1.12$ & $5.33 \pm 1.00$ & $7.57 \pm 1.39$ & $34.7+2.67 * \mathrm{LA}$ & $<0.001$ & $86 \%$ \\
\hline
\end{tabular}

* Significant for $\mathrm{P}<0.05 . \mathrm{R}^{2}$ : Determination coefficient for regression equation and predictors. PD: parietal diameter; $\mathrm{AD}$ : abdominal diameter; AA: abdominal area, FL: femur length, PT: placental thickness, CL: cardiac length, CW: cardiac width, CA: cardiac area; CV: cardiac volume; $\mathrm{HD}$ : hepatic diameter; LA: liver area. 
Table 3: Mean values of fetal biometry (cranium, abdominal, femoral, placentary, cardiac and hepatic) in Pug, during the 5th and 8th weeks of pregnancy

\begin{tabular}{cccccccc}
\hline Variables & 5th & 6th & 7th & 8th & Regression & P-value & $\mathbf{R}^{\mathbf{2}}$ \\
\hline $\mathrm{PD}(\mathrm{cm})$ & $1.02 \pm 0.23$ & $1.46 \pm 0.33$ & $1.85 \pm 0.29$ & $2.37 \pm 0.20$ & $24.2+12.7^{*} \mathrm{PD}$ & $<0.001$ & $80 \%$ \\
$\mathrm{AD}(\mathrm{cm})$ & $1.17 \pm 0.35$ & $2.13 \pm 0.31$ & $2.64 \pm 0.41$ & $3.34 \pm 0.29$ & $25.8+8.5^{*} \mathrm{AD}$ & $<0.001$ & $85 \%$ \\
$\mathrm{AA}\left(\mathrm{cm}^{2}\right)$ & $1.26 \pm 0.77$ & $3.83 \pm 1.54$ & $5.81 \pm 1.63$ & $9.52 \pm 2.27$ & $34.9+2.1 * \mathrm{AA}$ & $<0.001$ & $80 \%$ \\
$\mathrm{FL}(\mathrm{cm})$ & $0.44 \pm 0.18$ & $0.75 \pm 0.19$ & $1.13 \pm 0.25$ & $1.55 \pm 0.13$ & $30.1+15.9 * \mathrm{FL}$ & $<0.001$ & $84 \%$ \\
$\mathrm{PT}(\mathrm{cm})$ & $0.37 \pm 0.08$ & $0.44 \pm 0.07$ & $0.50 \pm 0.04$ & $0.50 \pm 0.12$ & $25.2+44.2^{*} \mathrm{TP}$ & 0.016 & $28 \%$ \\
$\mathrm{CL}(\mathrm{cm})$ & $0.57 \pm 0.22$ & $0.99 \pm 0.24$ & $1.35 \pm 0.22$ & $1.73 \pm 0.15$ & $27.8+15.2 * \mathrm{CL}$ & $<0.001$ & $84 \%$ \\
$\mathrm{CW}(\mathrm{cm})$ & $0.51 \pm 0.18$ & $0.75 \pm 0.12$ & $1.05 \pm 0.15$ & $1.25 \pm 0.20$ & $26.3+21.5 * \mathrm{CW}$ & $<0.001$ & $77 \%$ \\
$\mathrm{CA}\left(\mathrm{cm}^{2}\right)$ & $0.28 \pm 0.18$ & $0.59 \pm 0.20$ & $1.10 \pm 0.30$ & $1.61 \pm 0.37$ & $34.3+12.4^{*} \mathrm{CA}$ & $<0.001$ & $80 \%$ \\
$\mathrm{CV}\left(\mathrm{cm}^{3}\right)$ & $0.12 \pm 0.11$ & $0.31 \pm 0.12$ & $0.77 \pm 0.31$ & $1.56 \pm 0.77$ & $39.1+9.22^{*} \mathrm{CV}$ & $<0.001$ & $63 \%$ \\
$\mathrm{HD}\left(\mathrm{cm}^{2}\right.$ & $0.57 \pm 0.13$ & $1.05 \pm 0.64$ & $0.99 \pm 0.17$ & $1.23 \pm 0.20$ & $35.4+10.5^{*} \mathrm{HD}$ & 0.015 & $29 \%$ \\
$\mathrm{LA}\left(\mathrm{cm}^{2}\right)$ & $0.81 \pm 0.51$ & $2.28 \pm 1.48$ & $3.38 \pm 0.63$ & $4.38 \pm 1.24$ & $34.9+3.91^{*} \mathrm{LA}$ & $<0.001$ & $66 \%$
\end{tabular}

* Significant for $\mathrm{P}<0.05 . \mathrm{R}^{2}$ : Determination coefficient for regression equation and predictors. PD: parietal diameter; $\mathrm{AD}$ : abdominal diameter; AA: abdominal area, FL: femur length, PT: placental thickness, CL: cardiac length, CW: cardiac width, CA: cardiac area; CV: cardiac volume; $\mathrm{HD}$ : hepatic diameter; LA: liver area.

Table 4: Mean values of fetal biometry (cranium, abdominal, femoral, placentary, cardiac and hepatic) in Shih Tzu, during the 5th and 8th weeks of pregnancy

\begin{tabular}{cccccccc}
\hline Variables & 5th & 6th & 7th & 8th & Regression & P-value & $\mathbf{R}^{\mathbf{2}}$ \\
\hline $\mathrm{PD}(\mathrm{cm})$ & $1.10 \pm 0.14$ & $1.52 \pm 0.20$ & $2.00 \pm 0.22$ & $2.36 \pm 0.11$ & $20.2+14.5^{*} \mathrm{PD}$ & $<0.001$ & $88 \%$ \\
$\mathrm{AD}(\mathrm{cm})$ & $1.39 \pm 0.29$ & $2.26 \pm 0.31$ & $3.00 \pm 0.39$ & $3.59 \pm 0.24$ & $24.3+8.3^{*} \mathrm{AD}$ & $<0.001$ & $87 \%$ \\
$\mathrm{AA}\left(\mathrm{cm}^{2}\right)$ & $1.63 \pm 0.64$ & $3.92 \pm 1.20$ & $7.57 \pm 2.07$ & $10.14 \pm 1.53$ & $33.9+2.0^{*} \mathrm{AA}$ & $<0.001$ & $83 \%$ \\
$\mathrm{FL}(\mathrm{cm})$ & $0.43 \pm 0.10$ & $0.88 \pm 0.18$ & $1.21 \pm 0.20$ & $1.48 \pm 0.16$ & $28.6+16.8^{*} \mathrm{FL}$ & $<0.001$ & $83 \%$ \\
$\mathrm{PT}(\mathrm{cm})$ & $0.41 \pm 0.08$ & $0.51 \pm 0.10$ & $0.54 \pm 0.09$ & $0.57 \pm 0.08$ & $25.5+38.3^{*} \mathrm{TP}$ & $<0.001$ & $29 \%$ \\
$\mathrm{CL}(\mathrm{cm})$ & $0.70 \pm 0.15$ & $1.17 \pm 0.19$ & $1.50 \pm 0.21$ & $1.71 \pm 0.23$ & $25.0+16.0^{*} \mathrm{CL}$ & $<0.001$ & $77 \%$ \\
$\mathrm{CW}\left(\mathrm{cm}^{2}\right)$ & $0.53 \pm 0.11$ & $0.86 \pm 0.12$ & $1.09 \pm 0.17$ & $1.27 \pm 0.12$ & $24.3+22.4 * \mathrm{CW}$ & $<0.001$ & $80 \%$ \\
$\mathrm{CA}\left(\mathrm{cm}^{2}\right)$ & $0.28 \pm 0.11$ & $0.72 \pm 0.19$ & $1.26 \pm 0.28$ & $1.59 \pm 0.25$ & $32.8+13.0^{*} \mathrm{CA}$ & $<0.001$ & $84 \%$ \\
$\mathrm{CV}\left(\mathrm{cm}^{3}\right)$ & $0.10 \pm 0.06$ & $0.39 \pm 0.14$ & $0.92 \pm 0.34$ & $1.29 \pm 0.32$ & $36.4+13.2^{*} \mathrm{CV}$ & $<0.001$ & $77 \%$ \\
$\mathrm{HD}\left(\mathrm{cm}^{2}\right.$ & $0.54 \pm 0.12$ & $0.79 \pm 0.13$ & $1.11 \pm 0.25$ & $1.26 \pm 0.20$ & $27.2+19.6^{*} \mathrm{HD}$ & $<0.001$ & $70 \%$ \\
$\mathrm{LA}\left(\mathrm{cm}^{2}\right)$ & $0.89 \pm 0.47$ & $2.25 \pm 0.73$ & $4.16 \pm 1.09$ & $5.02 \pm 1.05$ & $33.8+3.75^{*} \mathrm{LA}$ & $<0.001$ & $77 \%$ \\
\hline
\end{tabular}

* Significant for $\mathrm{P}<0.05$. $\mathrm{R}^{2}$ : Determination coefficient for regression equation and predictors. PD: parietal diameter; AD: abdominal diameter; AA: abdominal area, FL: femur length, PT: placenta thickness, CL: cardiac length, CW: cardiac width, CA: cardiac area; CV: cardiac volume; $\mathrm{HD}$ : hepatic diameter; LA: liver area.

Table 5: Regression predictor equation for gestation days of fetal biometry in brachycephalic pregnant bitches

\begin{tabular}{cccc}
\hline Measurements & Regression Equation & P-value & $\mathbf{R}^{\mathbf{2}}$ \\
\hline $\mathrm{PD}(\mathrm{cm})$ & $\mathrm{GD}=23.0+13.1 * \mathrm{PD}$ & $<0.001$ & $81 \%$ \\
$\mathrm{AD}(\mathrm{cm})$ & $\mathrm{GD}=25.5+7.85 * \mathrm{AD}$ & $<0.001$ & $86 \%$ \\
$\mathrm{AA}\left(\mathrm{cm}^{2}\right)$ & $\mathrm{GD}=35.0+1.76 * \mathrm{AA}$ & $<0.001$ & $80 \%$ \\
$\mathrm{FL}(\mathrm{cm})$ & $\mathrm{GD}=29.2+16.0 * \mathrm{FL}$ & $<0.001$ & $84 \%$ \\
$\mathrm{PT}(\mathrm{cm})$ & $\mathrm{GD}=24.0+41.9 * \mathrm{TP}$ & 0.016 & $34 \%$ \\
$\mathrm{CL}(\mathrm{cm})$ & $\mathrm{GD}=25.9+15.5 * \mathrm{CL}$ & $<0.001$ & $79 \%$ \\
$\mathrm{CW}(\mathrm{cm})$ & $\mathrm{GD}=25.5+21.0 * \mathrm{CW}$ & $<0.001$ & $79 \%$ \\
$\mathrm{CA}\left(\mathrm{cm}^{2}\right)$ & $\mathrm{GD}=33.4+12.3 * \mathrm{CA}$ & $<0.001$ & $82 \%$ \\
$\mathrm{CV}\left(\mathrm{cm}^{3}\right)$ & $\mathrm{GD}=37.3+11.3 * \mathrm{CV}$ & $<0.001$ & $72 \%$ \\
$\mathrm{HD}\left(\mathrm{cm}^{2}\right)$ & $\mathrm{GD}=30.3+15.9 * \mathrm{HD}$ & 0.015 & $56 \%$ \\
$\mathrm{LA}\left(\mathrm{cm}^{2}\right)$ & $\mathrm{GD}=35.2+3.2 * \mathrm{LA}$ & $<0.001$ & $71 \%$ \\
\hline
\end{tabular}

* Significant for $\mathrm{P}<0.05 . \mathrm{R}^{2}$ : Determination coefficient for regression equation and predictors. PD: parietal diameter; $\mathrm{AD}$ : abdominal diameter; AA: abdominal area, FL: femur length, PT: placental thickness, CL: cardiac length, CW: cardiac width, CA: cardiac area; $\mathrm{CV}$ : cardiac volume; $\mathrm{HD}$ : hepatic diameter; $\mathrm{LA}$ : liver area. 
Gestational ultrasound in brachycephalic animals has proved to be essential to monitor pregnant females, both for an adequate estimate of whelping date and for a complete gestational monitoring. Additionally, the echo biometry to monitor pregnant bitches is a suitable and important ultrasonographic technique for veterinary obstetrics, assisting the early detection of maternal fetal dysfunctions, which can prejudice the gestational viability as observed by Miranda and Domingues $^{(2)}$ in pregnant bitches.

The gestational vesicles echo biometry, in this study, was efficient and of easy implementation, improving the early pregnancy diagnosis, which can be very important for professionals of the assisted reproduction area. According to Feliciano ${ }^{(1)}$, early diagnosis of pregnancy is important for the differentiation from diseases like pyometra, hemometra or mucometra.

Through the evaluation of gestational vesicles diameters in felines, Brito et al. ${ }^{(4)}$ obtained, at 15 days of gestation, the following mean values ELL: $1.28 \pm 0.05 \mathrm{~cm}$, ILL: $0.96 \pm 0.08 \mathrm{~cm}$, EDV: 1.13 $\pm 0.04 \mathrm{~cm}$ and IDV: $0.81 \pm 0.02 \mathrm{~cm}$. These results are different from those observed due to the first exam precocity $(14.2 \pm 2.04$ days after mating) and to the fact that the species evaluated were different.

Other studies also showed different values for echo biometry of gestational vesicles in bitches, since exams were performed at later moments and fewer echo biometric measurements were evaluated. For fetal and embryonic vesicle, Teixeira et al. ${ }^{(5)}$ obtained average values of $1.3 \pm 0.14$ to $4.1 \pm 0.15$ $\mathrm{cm}$, at 39 and 24 days before whelping, respectively.

In a study performed by Camargo's ${ }^{(6)}$, the fetuses of brachycephalic bitches of breeds such as French Bulldog, Pug and Shih-Tzu were evaluated for the biometric values placenta thickness, biparietal diameter, thoracic diameter, abdominal diameter, humerus length, femur length and heart rate, and relevant information for these breed groups was obtained. The present study complements the findings by Camargo ${ }^{(6)}$, providing additional results for fetal biometry measurements like heart and liver biometrics, besides using English bulldog dogs in the evaluation.

In this context, placenta thickness was obtained by a similar method as Carmago's ${ }^{(6)}$. Liver diameters of brachycephalic fetuses were the measures that did not have significant importance (P > 0.05); however, parietal diameter, abdominal diameter, abdominal area, femur length, cardiac length, cardiac width, cardiac area, cardiac volume and liver demonstrated significant importance $(\mathrm{P}>0.05)$ and considerable determination coefficient for regression equation and predictor (Table 5).

The evaluation of ultrasound images of the fetuses femoral echo biometry at different gestational weeks $(\mathrm{P}<0.005)$ has proved to be a useful measurement for estimating the gestational age $\left(\mathrm{r}^{2} 81 \%\right)$, similar to Camargo ${ }^{(6)}$. Additionally, we believe that this measurement can assist in monitoring bones development, for early detection of underdeveloped fetuses and congenital diseases, such as agenesis and hypoplasia of long bones and hypothyroidism (dwarfism by shortened limbs), as cited by Greco ${ }^{(7)}$ and Wisner and Pollard ${ }^{(8)}$.

The results for echo biometry of the fetal femur differ from Teixeira et al. ${ }^{(5)}$, who obtained average values of 1.1 to $2.0 \mathrm{~cm}$ between 18 and 3 days before whelping, respectively, in Rottweiler. Jabin et al. ${ }^{(9)}$ reported values of $1.10 \pm 0.18 \mathrm{~cm}$ between 36 and 40 days of pregnancy in York Shire. Brito et al. ${ }^{(4)}$ found average values of $1.46 \pm 0.02 \mathrm{~cm}$ and $1.58 \pm 0.01 \mathrm{~cm}$ at $43 \mathrm{rd}$ and 48th gestational day, respectively, in fetal cats. The difference can be explained by variations in breeds among the studies and the weekly monitoring in this study, not reported in veterinary medicine yet.

The characterization of uterine placental layers and/or typical zonary placenta (thickness) was 
similar to sonography findings observed by Almeida et al. ${ }^{(10)}$. The values found in the evaluation of placenta thickness may support the diagnosis of placental disorders associated to diameter changes like placentitis and hydrops, which are poorly reported in the literature, leading to embryonic death or abortion ${ }^{(11)}$. However, this measurement cannot be used to predict the gestational age of brachycephalic dogs, similar to that observed by Carmago ${ }^{(6)}$.

Abdominal diameter increased linearly during all gestational stages of the animals, accompanying the development of abdominal organs. This measurement presented good correlation with gestational age $(86 \%)$ similar to that observed by Camargo ${ }^{(6)}$. The abdominal area is a new measure that also proved to be of great value to the echo biometric study of canine fetuses.

Teixeira et al. ${ }^{(5)}$ obtained, at 32 and 3 days before whelping, average values of $0.9 \pm 0.50 \mathrm{~cm}$ and $5.1 \pm 0.05 \mathrm{~cm}$, respectively, for abdominal diameter in canine fetuses. These data differ from those obtained in this study and breed variation can be correlated. In humans, congenital changes in abdominal organs of fetuses can be correlated to reduced values of fetal abdominal diameter. ${ }^{(12)}$ Thus, great is the importance of weekly evaluation by measuring the diameter of the abdominal area, performed in this study, obtaining reference values to detect canine congenital gestational diseases in English Bulldog, Pug and Shih Tzu dogs. There are few reports ${ }^{(12)}$ about the fetal echo biometry measurements in veterinary practice and the values obtained can also assist in the early detection of fetal malformations.

For the parietal diameter, the results obtained in this study corroborate the ones by Jabin et al. ${ }^{(9)}$, who obtained values of $2.35 \pm 0.07 \mathrm{~cm}$ at 63 days of gestation in bitches, and those described by Brito et al. ${ }^{(4)}$, who found average values of $1.12 \pm 0.03 \mathrm{~cm}, 1.47 \pm 0.03 \mathrm{~cm}$ and $1.83 \pm 0.02 \mathrm{~cm}$ at 37, 43 and 50 days of gestation in bitches, respectively. These values are important in the evaluation of fetal development and also assist in determining an estimated gestational age $\left(\mathrm{P}<0.05 ; \mathrm{r}^{2} 81 \%\right)$ by ultrasonography.

The evaluation of the cardiovascular system of canine fetuses by the movement of cardiac fibers is described since $26.7 \pm 2.2$ days of gestation ${ }^{(2)}$. The presence of fetal heartbeat is assessed by ultrasonography, as well as the detection of large vessels and the development of fetal heart (presence of valves and chambers) ${ }^{(1)}$. Complementing the study of the cardiovascular system of the fetus, this study was able to determine areas, volumes, lengths and widths of the heart from the fifth week of gestation on, so far unreported in veterinary obstetrics. It is suggested that the data obtained can assist the detection of cardiomegaly, microcardia or tetralogy of Fallot as described in human medicine by Poon et al. ${ }^{(13)}$.

Regarding the use of cardiac measurements to estimate the gestational age, there is no description in veterinary obstetrics of these values of canine fetal biometry. The results for the cardiac length, width, area and volume were significant $(\mathrm{P}<0.05)$ and with good correlation to estimate the gestational age $(79 \%, 79 \%, 82 \%$ and $72 \%$, respectively).

Other unpublished evaluations conducted in this study were the determination of the liver diameter and area of canine fetuses. The values for the hepatic diameter were not significant $(\mathrm{P}=0.015)$ and we cannot consider them as predictive $(56 \%)$ for gestational age. However, the liver area of brachycephalic fetuses showed a significant increase $(\mathrm{P}<0.05)$ during pregnancy, which can be used to measure the gestational age $(71 \%)$ of bitches. The use of these measurements in dogs can be justified by ultrasound findings in human neonates cited by Roberts et al. ${ }^{(14)}$, which relate to a high mortality rate for children with reduced liver size since gestational life. The liver echo biometry can be used for early detection of microhepatia, which might suggest portosystemic abnormalities ${ }^{(15,16)}$. 
It is important to comment on some of the limitations observed this study: it provides important information about the fetal echo biometrics of brachycephalic setting unpublished reference values for dogs; however, it is necessary to conduct more studies with larger number of animals and include other brachycephalic breeds, such as French Bulldog.

\section{Conclusion}

This study obtained important and unpublished values of biometry of gestational vesicles, fetal development and equations to estimate the gestational age of the breeds: English Bulldog, Pug and Shih Tzu. The results obtained for biometrics of parietal and abdominal diameter, abdominal area, femur length, cardiac length and width, cardiac area and volume and liver area in brachycephalic conceptus may help assessing the development of fetuses, complementing the conventional ultrasound of pregnant bitches and be a model for the study in alternative breeds of dogs and other animal species.

\section{Ackowledgements}

The authors thank FAPESP for the scholarship and grant aid for post-doctoral research (process 2010/16913-7 and 2011/06011-9).

\section{References}

1. Feliciano MAR, Muzzi LAL, Leite CAL, Junqueira MA. Two-dimensional conventional, high resolution two-dimensional and three-dimensional ultrasonography in the evaluation of pregnant bitch. Brazilian Journal of Veterinary and Animal Science. 2007; 59(5):1333-1337.

2. Miranda SA, Domingues SFS. Conceptus ecobiometry and triplex Doppler ultrasonography of uterine and umbilical arteries for assessment of fetal viability in dogs. Theriogenology. 2010; 74(4):608-617.

3. Feliciano MAR, Nepomuceno AC, Cardilli DJ, Coutinho LN, Oliveira MEF, Almeida VT, Canello FG, Vicente WRR. B-mode ultrasound and doppler mode for early-stage pregnancy diagnosis in shi-tzu bitches. Acta Scientiae Veterinariae. 2013; 41:1160.

4. Brito AB, Miranda SA, Ruas MR, Santos RR, Domingues SFS. Assessment of feline fetal viability by conceptus echobiometry and triplex Doppler ultrasonography of uterine and umbilical arteries. Animal Reproduction Science. 2010; 122(3-4):276-281.

5. Teixeira MJ, Souza DMB, Melo KCM, Wischral, A. Estimation of parturition date through ultrasonographic foetal biometry in rottweiler bitches. Ciência Animal Brasileira. 2009; 10(3):853-861.

6. Camargo NI (2012). Estimativa da idade gestacional por biometria fetal através de exames ultrassonográficos em cadelas (Canis familiaris, Linnaeus, 1758) das raças Bulldog Francês, Pug e Shih Tzu. 66f. Dissertação (Mestrado em Ciência Veterinária), Universidade Federal de Pernambuco, Recife. Disponível em: <http://200.17.137.108/tde busca/arquivo.php?codArquivo=1470>. Acesso em janeiro de 2015.

7. Greco DS, Feldman EC, Peterson ME, Turner JL, Connie MH, Shipman W. Congenital hypothyroid 
dwarfism in a family of giant schnauzers. Journal of Veterinary Internal Medicine. 1991; 5(2):57-65.

8. Wisner ER, Pollard RE. Doenças ortopédicas de cães e gatos jovens e em crescimento. In: Thrall DE. Textbook of Veterinary Diagnostic Radiology. 5th ed. St Louis: Elsevier; 2010. p. 268-283. Portuguese

9. Jabin VCP, Finardi JC, Mendes FCC, Weiss RR, Kozicki LE, Moraes R. Use of ultrasonography exams to determinate the parturition day by Yorkshire canine breed. Archives of Veterinary Science. 2007; 12(1):6370 .

10. Almeida AH, Sterman FA, Miglino MA. Ultrasonographic mensuration of head dimentions in boxers normal gestations and its correlation with the gestational age. Brazilian Journal of Veterinary Research and Animal Science. 2003; 40:136-140.

11. Cardoso RCS. Infertilidade na gata e na cadela. Ciência Animal. 2012; 22(1):235-247.

12. Zone MA, Wanke MM. Diagnosis of canine fetal health by ultrasonography. Journal of Reproduction \& Infertility. 2001; 57:215-219.

13. Poon LC, Huggon IC, Zidere V, Allan LD. Tetralogy of Fallot in the fetus in the current era. Ultrasound in Obstetrics \& Gynecology. 2007; 29(6):625-627.

14. Roberts AB, Mitchell JM, Mccowan LM, Barker S. Ultrasonographic measurement of liver length in the small-for- gestational-age fetus. American Journal of Obstetetrics \& Gynecology. 1999; 180(3 Pt. 1):634638.

15. Feliciano MAR, Leite CAL, Nepomuceno AC, Silveira T, Muzzi RAL, Vicente WRR. Ultrasonographic evaluation of portosystemic vascular anomaly in dog: a case report. Brazilian Journal of Veterinary and Animal Science. 2009; 61(3):585-589. Available from: < http://dx.doi.org/10.1590/S010209352009000300010>. Acesso em dezembro 2014.

16. Koide K, Koide Y, Wada Y, Nakaniwa S, Yamane Y. Congenital hepatic arteriovenous fistula with intrahepatic portosystemic shunt and aortic stenosis in a dog. Journal of Veterinary Medicine Science. 2004; 66(3):299-302. 